\title{
Complementarities between Outsourcing and Foreign Sourcing
}

\section{Citation}

Grossman, Gene M, Elhanan Helpman, and Adam Szeidl. 2005. “Complementarities between Outsourcing and Foreign Sourcing." American Economic Review95 (2): 19-24. https:// doi.org/10.1257/000282805774670518.

\section{Permanent link}

http://nrs.harvard.edu/urn-3:HUL.InstRepos:41534584

\section{Terms of Use}

This article was downloaded from Harvard University's DASH repository, and is made available under the terms and conditions applicable to Other Posted Material, as set forth at http:// nrs.harvard.edu/urn-3:HUL.InstRepos:dash.current.terms-of-use\#LAA

\section{Share Your Story}

The Harvard community has made this article openly available.

Please share how this access benefits you. Submit a story.

Accessibility 
Complementarities between Outsourcing and Foreign Sourcing

By

Gene M. Grossman,

Elhanan Helpman

and

Adam Szeidl

Working Paper No. 1-2005

January, 2005

The Foerder Institute for Economic Research

and

The Sackler Institute of Economic Studies 


\title{
Complementarities between Outsourcing and Foreign Sourcing*
}

\author{
by \\ Gene M. Grossman \\ Princeton University \\ Elhanan Helpman \\ Harvard University \\ and \\ Adam Szeidl \\ University of California, Berkeley
}

October 12, 2004

\begin{abstract}
We examine the strategies of firms that face an array of organizational choices. Each firm must acquire intermediate inputs and assemble final products. It can perform these activities internally or externally, and at home or abroad. We study the relative prevalence of various organizational structures in industries that differ in fixed organizational costs when firms in each industry differ in their productivity levels. We identify conditions under which outsourcing and foreign sourcing are positively correlated across industries. This correlation results from two sources of complementarity between outsourcing and foreign sourcing.
\end{abstract}

JEL Classification: F23, F12, L22

Keywords: outsourcing, integration, foreign direct investment, complementarity.

\footnotetext{
*We acknowledge with thanks the support of the National Science Foundation and the US-Israel Binational Science Foundation.
} 


\section{Introduction}

Outsourcing has been growing both domestically and internationally. So has foreign direct investment (FDI). New models of international trade address these phenomena using recent advances in the economic theory of organizations. The models help us to identify circumstances under which firms choose to make their inputs themselves or buy them from third parties, and when they choose to produce or procure their inputs locally or abroad. ${ }^{1}$ Some authors investigate the organizational choices of homogeneous firms in an industry with some particular characteristics while others examine the relative prevalence of different organizational structures in industries with heterogeneous firms. ${ }^{2}$

In this paper, we combine elements from Antràs and Helpman (2004) and Grossman, Helpman and Szeidl (2004) to study the relationship between outsourcing and foreign sourcing (or "offshoring"). Our analysis focuses on industries with heterogeneous firms that make intensive use of intermediate inputs. Contracting problems limit the types of contracts that can be written between final producers and input suppliers. Intermediate inputs can be produced domestically or in a low-wage country, and can be produced in house or outsourced. By assumption, assembly of final goods takes place within the boundaries of the firm that has developed the product, but we sometimes allow this activity to be performed abroad.

First, we assume that assembly takes place at home and that intermediate goods can be transported at no cost. We identify conditions under which cross-industry variation in the fixed cost of outsourcing generates a positive correlation between outsourcing and foreign sourcing. We then introduce transport costs for intermediate inputs and allow firms to choose where to assemble their final output. In this case, cross-industry variation in the fixed cost of doing business abroad produces a second complementarity between outsourcing and foreign sourcing. The latter finding is in keeping with conditions described in a recent article in the Financial Times about problems facing firms producing in China. ${ }^{3}$ Companies that cannot find efficient local sources for components in China are burdened with the extra costs of shipping inputs from home. Apparently, FDI often goes hand in hand with the ability to find suitable Chinese suppliers. The trade-offs between in house production and outsourcing and between shipping intermediate goods and producing them in proximity to assembly operations are the subject of our investigation below.

\footnotetext{
${ }^{1}$ See Grossman and Helpman (2002), Marin and Verdier (2002,2003), Puga and Trefler (2002), Antràs (2003), Antràs and Helpman (2004), Grossman and Helpman (2004), and Grossman and Helpman (2005).

${ }^{2}$ Melitz (2003) has developed a model of heterogeneous firms that is commonly used in this literature; see Antràs and Helpman (2004) and Grossman and Helpman (2004).

${ }^{3}$ See Marsh (2004).
} 


\section{The Model}

Our model combines elements from Antràs and Helpman (2004) and Grossman, Helpman and Szeidl (2004). There are two countries, North and South, and one factor of production, labor. The wage rate is $w^{N}$ in the North and $w^{S}$ in the South, with $w^{N}>w^{S}$. We normalize prices so that $w^{N}=1$.

Consumers have Dixit-Stiglitz preferences for differentiated products which generate the inverse demand function $p_{j}(i)=D_{j} x_{j}(i)^{-(1-\alpha)}$ for variety $i$ of good $j$, where $p_{j}(i)$ is the price of this variety, $x_{j}(i)$ is the quantity demanded, $D_{j}$ is an index of total demand for the output of industry $j$, and $\alpha$ is a parameter that determines the elasticity of demand. We assume $0<\alpha<1$, so that the elasticity of demand is larger than one. All final goods are freely traded with zero transport costs. Thus, prices of final goods are the same in both countries and $D_{j}$ measures world demand for the output of industry $j$.

Entrepreneurs are located in the North. To enter a market and produce any variety, an entrepreneur first must incur a fixed cost of $f_{E}$ units of Northern labor. An entrant then draws a productivity level $\theta$ from a cumulative distribution $G(\theta)$. Having learned $\theta$, the entrepreneur decides whether and how to produce final goods or whether to exit the market.

Production requires two inputs, assembly $a_{j}(i)$ and intermediate inputs $m_{j}(i) .{ }^{4}$ These inputs must be specialized to variety $i$ of product $j$; otherwise, they cannot be combined to produce final output. Output from specialized inputs is given by

$$
x_{j}(i)=\theta\left[\frac{a_{j}(i)}{\eta_{j}}\right]^{\eta_{j}}\left[\frac{m_{j}(i)}{1-\eta_{j}}\right]^{1-\eta_{j}}, 0<\eta_{j}<1,
$$

where $\eta_{j}$ is a sector-specific technological parameter. Higher values of $\eta_{j}$ correspond to production technologies that make more intensive use of the assembly activity. Assembly and production of intermediate inputs can be performed in the North or in the South. One unit of $a_{j}(i)$ or $m_{j}(i)$ requires one unit of local labor wherever the activity is performed.

There are two types of agents, entrepreneurs who develop and assemble final goods and manufacturers who produce intermediate inputs. We use $F$ to denote the former and $M$ to denote the latter. Every active $F$ agent must contract with an $M$ agent for the supply of intermediate inputs. The $F$ agents are located in the North, where they develop their unique brands of the final good. Some $M$ agents are located in the North and others in the South.

In what follows, we focus on a particular industry $j$ and omit the index $j$ from the relevant variables. After bearing the entry cost $f_{E}$ and learning his productivity $\theta$, an $F$ agent approaches an $M$ agent in either the North or the South. In each location, there is an infinitely elastic supply of such agents all of whom have an outside option normalized to zero. An $F$ agent offers his potential partner a contract that specifies a fixed payment.

\footnotetext{
${ }^{4}$ One may think about $a$ and $m$ as quality-adjusted effective units of the inputs rather than as quantities, with the quantity of each input normalized to one.
} 
The specified payment from $F$ to $M$ may be positive or negative, and the offer is made on a take-it-or-leave-it basis. The $F$ agent anticipates that, if he accepts the offer, his earnings will include the contracted payment plus a fraction of profits. Profit sharing results from ex post bargaining once the inputs have been produced. The profit shares reflect the organization of the enterprise (see below), which $F$ is free to choose. The $F$ agent sets the contractual payment to provide his partner with an expected net reward of zero. All such offers are accepted.

For now we assume that assembly can be conducted only in the North. An organizational form consists of an ownership structure and a location of $M$, denoted by $\{k, l\}$, where $k$ is either $I$ or $O$ (integration or outsourcing) and $l$ is either $N$ or $S$ (North or South). The fixed cost of maintaining an organizational structure $\{k, l\}$ is $f_{k}^{l}$ in units of Northern labor. We assume that $f_{k}^{l}$ is separable and write it as $f_{k}^{l}=f^{l}+f_{k}$.

In contrast to Antràs and Helpman (2004), we assume that the fixed organizational cost of integration is less than the fixed cost of outsourcing, i.e., $f_{I}<f_{O} .{ }^{5}$ But like Antràs and Helpman, we assume that doing business in the South is more costly than doing business at home; i.e., $f^{N}<f^{S}$. For simplicity we also assume that $f^{N}=f_{I}=0$. Thus

$$
f_{I}^{N}=0<f_{O}^{N}=f_{O}<f_{O}^{S}=f_{O}+f^{S} \text { and } f_{I}^{S}=f^{S}<f_{O}^{S}=f_{O}+f^{S} .
$$

Contracts are incomplete. They specify only the sizes and directions of the fixed payments, leaving the agents to bargain over surplus after the inputs have been produced. We assume Nash bargaining in which $F$ captures a share $\beta \in(0,1)$ of the surplus from his relationship with $M$. The potential revenue is $R(i) \equiv p(i) x(i)=D x^{\alpha}$, which, using (1), can be expressed as

$$
R(i)=D \theta^{\alpha}\left[\frac{h(i)}{\eta}\right]^{\alpha \eta}\left[\frac{m(i)}{1-\eta}\right]^{\alpha(1-\eta)} .
$$

To determine the bargaining outcome, we need to consider the agents' outside options. The outside option for $M$ always is zero, because $m(i)$ is tailored specifically to the product $i$. Similarly, the outside option for $F$ is zero if the organizational form involves outsourcing. However, with integration, $F$ enjoys property rights to the inputs produced by $M$. Since he owns these inputs, he can use them even if his partnership with $M$ dissolves. But we assume that failure to cooperate with $M$ is costly to $F$; without $M$, the entrepreneur can attain only a fraction $\delta$ of the output described by (1). For simplicity we assume that $\delta \in(0,1)$ is the same in the North and the South. Therefore, under integration, $F$ has an outside option of

\footnotetext{
${ }^{5}$ The switch in this assumption leads to a switch in the ordering of outsourcing and integration according to productivity. While in Antràs and Helpman (2004) outsourcing is chosen by less productive firm, in our case it is chosen by more productive firms. Our assumption is appropriate when the economies of scope in management exceed the managerial overload from integration, while the reverse assumption is appropriate in the opposite case. The complementarities emphasized in this paper are clearest in the case discussed here, of separable fixed costs and more costly outsourcing.
} 
$\delta^{\alpha} R(i)$.

Given this bargaining framework, the entrepreneur $F$ receives the fraction $\beta_{O}$ of $R(i)$ under outsourcing and the fraction $\beta_{I}=\delta^{\alpha}+\beta_{O}\left(1-\delta^{\alpha}\right)$ under integration, where $\beta_{I}>$ $\beta_{O}$. That is, the outside option allows $F$ to capture a larger fraction of the surplus under integration than under outsourcing. Once $F$ selects an organizational form $\{k, l\}$, the quantity of intermediate inputs is chosen by $M$ to maximize $\left(1-\beta_{k}\right) R(i)-w^{l} m(i)$, while the quantity of assembly is chosen by $F$ to maximize $\beta_{k} R(i)-a(i)$. We assume for the time being that intermediate inputs can be traded costlessly. In the event, operating profits for $\{k, l\}$ are given by

$$
\pi_{k}^{l}(\Theta)=D^{\frac{1}{1-\alpha}} \Theta \psi_{k}^{l}-f_{k}^{l}
$$

where $\Theta=\theta^{\alpha /(1-\alpha)}$ is a variant of our productivity measure and

$$
\psi_{k}^{l}=\frac{1-\alpha\left[\beta_{k} \eta+\left(1-\beta_{k}\right)(1-\eta)\right]}{\left[\left(\frac{1}{\alpha}\right)\left(\frac{1}{\beta_{k}}\right)^{\eta}\left(\frac{w^{l}}{1-\beta_{k}}\right)^{1-\eta}\right]^{\alpha /(1-\alpha)}} .
$$

As explained in Antràs and Helpman (2004), if production of final output makes sufficiently intensive use of intermediate inputs ( $\eta$ is small enough), then $\psi_{k}^{l}$ declines with $\beta_{k}$ and $\psi_{I}^{l}<$ $\psi_{O}^{l}$. If, on the other hand, production makes sufficiently intensive use of assembly, then $\psi_{k}^{l}$ rises with $\beta_{k}$ and $\psi_{I}^{l}>\psi_{O}^{l}$.

Since $F$ appropriates all of the operating profits via his choice of the contractual fixed payment, he opts for the organizational form $\{k, l\}$ that generates the largest value of $\pi_{k}^{l}(\Theta)$. Evidently, the organizational choice varies with the productivity of the firm. Also, since the fixed cost of integration in the North is zero, no final good producer exits the market for any productivity draw.

\section{Organizational Forms}

We analyze the organizational choices of firms that differ in their productivity levels. Two complementarities between outsourcing and foreign sourcing are reflected in the equilibrium choices.

\subsection{Complementarity I}

In the discussion of the first complementarity, we maintain the assumption that there are no transport costs of intermediate inputs or final goods. We also assume - as we do for the remainder of the paper - that production is intensive in the use of intermediate inputs, so that operating profits are declining in $\beta_{k}$. When this is true, providing better incentives for $M$ is more important to $F$ than is appropriating a larger fraction of the revenue. This consideration 


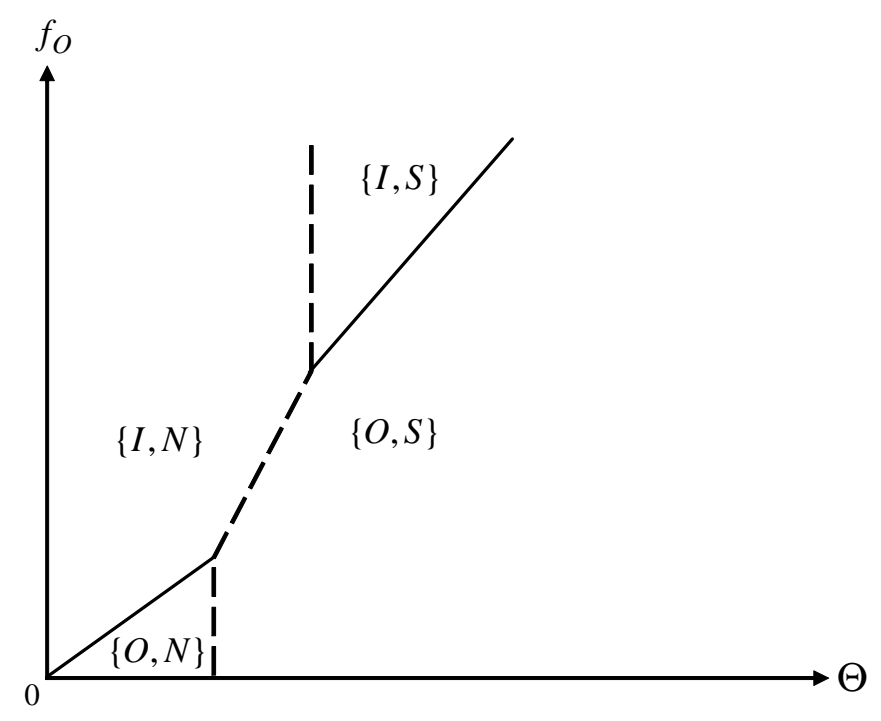

Figure 1: Organizational form with no trade costs

gives outsourcing an advantage over integration. On the other hand, outsourcing entails a greater fixed cost. Thus, there is a trade-off between outsourcing and integration, which leads more productive firms to outsource and less productive firms to integrate. The more productive firms choose to grant ownerships rights to the intermediate inputs in the hands of the manufacturer, because it is profitable for them to produce larger volumes of output and they thus benefit more from preserving the incentives for $M$ to produce large quantities of $m(i)$.

We show in the appendix that $F$ agents select their organization according to the pattern depicted in Figure 1. There are four regions, $\{I, S\},\{I, N\},\{O, S\}$ and $\{O, N\}$, each corresponding to a different organizational form. The first index describes the ownership structure, $I$ or $O$, while the second describes the location of $M$, in $N$ or in $S$. For example, $\{I, S\}$ describes a vertically integrated firm that produces intermediate inputs in the South. This strategy involves foreign direct investment (FDI), because inputs are produced in a foreign subsidiary. The figure focuses on variations in productivity, $\Theta$, and variations in the fixed cost of outsourcing, $f_{O}$. The value of $f_{O}$ is fixed in a given industry, but varies across industries. Productivity varies across firms in a given industry. The figure shows that in a given industry the most productive firms outsource in the South while the least productive firms integrate in the North. Firms with intermediate productivity levels either outsource in the North or integrate in the South.

The figure portrays a complementarity between the ownership structure and the location of production: in an industry in which a larger fraction of firms engage in outsourcing, a larger fraction of firms source their intermediate inputs in the South. The broken line depicts the boundary along which firms are indifferent between manufacturing intermediate inputs 
in the South and in the North. This line is upward sloping for an intermediate range of $f_{O}$, implying that the share of entrepreneurs who choose $M$ agents in the South is larger the smaller is the fixed cost of outsourcing. Therefore, cross-industry variation in the fixed cost of outsourcing generates a positive correlation between outsourcing and the sourcing of intermediate inputs in the South.

\subsection{Complementarity II}

We now extend the model to allow for costly transport of intermediate inputs. To make this analysis interesting, we allow $F$ to locate assembly in the South or in the North. But we continue to assume that $F$ controls the assembly activity; i.e., that assembly is integrated with product design. Then the only new option available to $F$ is to conduct FDI in assembly, which entails an extra fixed cost of $g_{I}^{S}=g^{S}>0$. This extra cost means that $F$ has no reason to locate assembly in the South unless it is costly to transport intermediate inputs. Thus, the introduction of an FDI option would not matter without the assumption of costly transport.

Transport costs take the "iceberg" form. A firm must ship $\tau>1$ units of the intermediate input from the South in order that one unit arrives in the North. Bargaining takes place after the intermediate inputs have arrived at their destination. Therefore, the effective marginal cost of producing intermediates in the South for delivery in the North is $\tau w^{S}$. The operating profits for a firm that assembles final goods in country $j$, produces intermediates in country $l$, and has an ownership structure $k$ are given by

$$
\pi_{k}^{j, l}(\Theta)=D^{\frac{1}{1-\alpha}} \Theta T^{j, l} \psi_{k}^{j, l}-f_{k}^{l}-g_{k}^{j}
$$

where $g_{I}^{S}=g^{S}>0, g_{I}^{N}=g_{O}^{S}=g_{O}^{N}=0$,

$$
T^{j, l}=\left\{\begin{array}{lc}
\tau^{-(1-\eta) \alpha /(1-\alpha)} & \text { if } j \neq l \\
1 & \text { otherwise }
\end{array},\right.
$$

and

$$
\psi_{k}^{j, l}=\frac{1-\alpha\left[\beta_{k} \eta+\left(1-\beta_{k}\right)(1-\eta)\right]}{\left[\left(\frac{1}{\alpha}\right)\left(\frac{w^{j}}{\beta_{k}}\right)^{\eta}\left(\frac{w^{l}}{1-\beta_{k}}\right)^{1-\eta}\right]^{\alpha /(1-\alpha)}} .
$$

This leaves us with eight potential organizational forms, indexed by $\{k, l, j\}$, where $k=I$ or $O, l=N$ or $S$, and $j=N$ or $S$. As before, $k$ represents the ownership structure and $l$ represents the location of $M$, while the new index $j$ represents the location of assembly.

To economize on the number of cases, we assume that $\tau$ is large, so that separation of production of intermediate inputs and assembly by $F$ never is profitable. Then $F$ chooses an organizational form from among the remaining alternatives, which are $\{O, N, N\},\{I, N, N\}$, $\{O, S, S\}$, and $\{I, S, S\}$. 


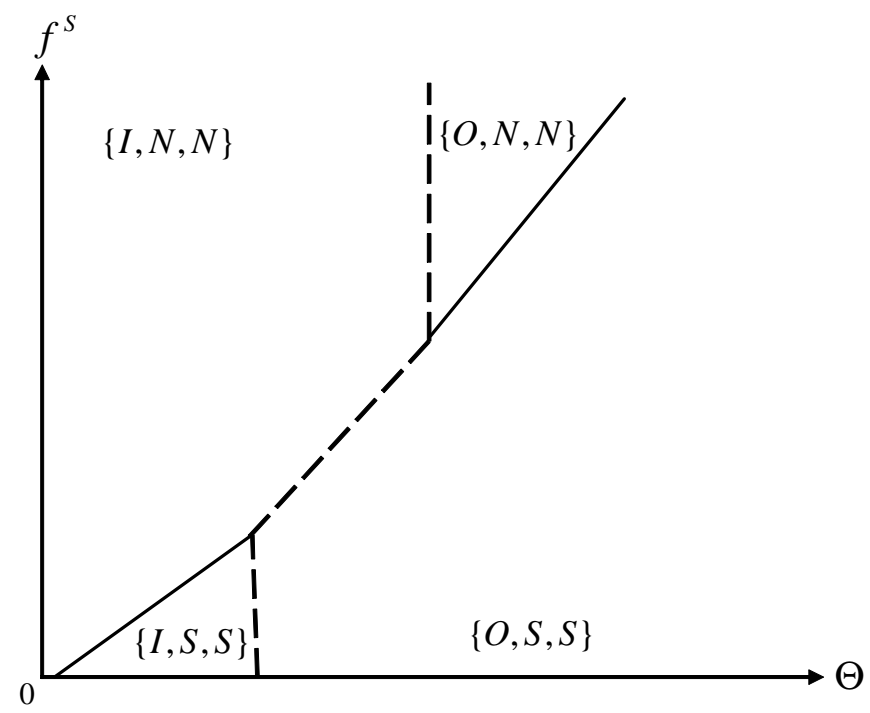

Figure 2: Organizational form with trade costs

We show in the appendix that Figure 2 depicts the equilibrium choices. For a fixed $f^{S}$, the most productive firms outsource the production of intermediate inputs in the South and assemble final goods abroad, while the least productive firms produce intermediate inputs in house and perform all activities in the North. In industries with lower fixed costs $f^{S}$, a larger fraction of firms source their intermediate inputs and conduct assembly in the South, and a larger fraction of firms outsource the production of parts. We have thus identified another complementarity between outsourcing and offshoring. As in Grossman, Helpman and Szeidl (2004), the manufacturing of intermediate inputs and assembly gravitate to the same country as a means to conserve on transportation costs. While it is more profitable to locate these activities in the South the lower is the fixed cost $f^{S}$, lower $f^{S}$ also makes outsourcing more profitable, because production in the South reduces unit cost and makes it profitable to produce a larger volume of output. When large quantities are desirable, outsourcing is attractive, because manufacturers have better incentives to produce parts. It follows that variations in the fixed cost of foreign sourcing produce a positive correlation between the fraction of firms that outsource and the fraction that source their intermediate inputs in the South.

Finally, we note that a very similar figure would apply if we were to consider variation in integration strategies as a function of the fixed cost $g^{S}$, instead of the cost $f^{S}$. Both parameters reflect the cost of doing business in the South. Given that manufacturing and assembly are always located in the same country due to high transport costs for intermediate inputs, the roles played by the fixed costs associated with these two activities are similar. 


\section{Appendix}

\section{Construction of Figure 1}

First note that there are four possible organizational forms, indexed by $\{I, S\},\{I, N\}$, $\{O, S\}$ and $\{O, N\}$. The profit of each organizational form is a linear function of $\Theta$, given by equation (4). Thus, we can determine the cutoff productivity level between $\{I, N\}$ and $\{I, S\}$ by equating the corresponding profit functions, $\pi_{I}^{N}\left(\Theta_{I N, I S}\right)=\pi_{I}^{S}\left(\Theta_{I N, I S}\right)$, and solving for

$$
\Theta_{I N, I S}=\frac{f_{I}^{S}-f_{I}^{N}}{D^{1 /(1-\alpha)}\left(\psi_{I}^{S}-\psi_{I}^{N}\right)}=\frac{f^{S}}{D^{1 /(1-\alpha)}\left(\psi_{I}^{S}-\psi_{I}^{N}\right)} .
$$

This expression does not depend on $f_{O}$. Therefore, the corresponding boundary in $\left(\Theta, f_{O}\right)$ space is a vertical line. Similarly, the cutoff productivity level

$$
\Theta_{O N, O S}=\frac{f_{O}^{S}-f_{O}^{N}}{D^{1 /(1-\alpha)}\left(\psi_{O}^{S}-\psi_{O}^{N}\right)}=\frac{f^{S}}{D^{1 /(1-\alpha)}\left(\psi_{O}^{S}-\psi_{O}^{N}\right)}
$$

does not depend on $f_{O}$. Moreover, we have $\Theta_{O N, O S}<\Theta_{I N, I S}$ if and only $\psi_{O}^{S}-\psi_{O}^{N}>\psi_{I}^{S}-\psi_{I}^{N}$, or if and only if

$$
\left[\frac{1}{\left(w^{S}\right)^{(1-\eta) \alpha /(1-\alpha)}}-1\right] \psi_{O}^{N}>\left[\frac{1}{\left(w^{S}\right)^{(1-\eta) \alpha /(1-\alpha)}}-1\right] \psi_{I}^{N}
$$

Our assumptions imply $\beta_{I}>\beta_{O}$, and - since production is intensive in intermediate inputs - $\beta_{I}>\beta_{O}$ implies $\psi_{I}^{l}<\psi_{O}^{l}$, which in turn implies the inequality in (A1) (recall that $\left.w^{S}<1\right)$. As a consequence, $\Theta_{O N, O S}<\Theta_{I N, I S}$.

To complete the construction of Figure 1, note that the cutoff productivity between $\{O, N\}$ and $\{I, N\}$ is

$$
\Theta_{O N, I N}=\frac{f_{O}^{N}-f_{I}^{N}}{D^{1 /(1-\alpha)}\left(\psi_{O}^{N}-\psi_{I}^{N}\right)}=\frac{f_{O}}{D^{1 /(1-\alpha)}\left(\psi_{O}^{N}-\psi_{I}^{N}\right)} .
$$

Therefore, the corresponding boundary in Figure 1 is a ray through the origin. As long as $\Theta$ is below $\Theta_{O N, O S}$, for fixed costs $f_{O}$ above this ray the firm chooses integration and for fixed costs below the ray it chooses to outsource. In the range where $\Theta_{O N, O S}<\Theta<\Theta_{I N, I S}$, we have

$$
\Theta_{I N, O S}=\frac{f_{O}^{S}-f_{I}^{N}}{D^{1 /(1-\alpha)}\left(\psi_{O}^{S}-\psi_{I}^{N}\right)}=\frac{f^{S}+f_{O}}{D^{1 /(1-\alpha)}\left(\psi_{O}^{S}-\psi_{I}^{N}\right)} .
$$

That is, the boundary between $\{I, N\}$ and $\{O, S\}$ is an upward-sloping line. Finally, for $\Theta>\Theta_{I N, I S}$ we have

$$
\Theta_{I S, O S}=\frac{f_{O}^{S}-f_{I}^{S}}{D^{1 /(1-\alpha)}\left(\psi_{O}^{S}-\psi_{I}^{S}\right)}=\frac{f_{O}}{D^{1 /(1-\alpha)}\left(\psi_{O}^{S}-\psi_{I}^{S}\right)},
$$


which also is a ray through the origin.

\section{Construction of Figure 2.}

We follow the same procedure as with Figure 1 . Since now we vary $f^{S}$, the fixed cost of manufacturing in the South, the boundaries between $\{O, N, N\}$ and $\{I, N, N\}$ and between $\{O, S, S\}$ and $\{I, S, S\}$ are vertical lines. Note that $\Theta_{I S S, O S S}<\Theta_{I N N, O N N}$ if and only if $\psi_{O}^{S, S}-\psi_{O}^{N, N}>\psi_{I}^{S, S}-\psi_{I}^{N, N}$, or equivalently, if and only if

$$
\left[\frac{1}{\left(w^{S}\right)^{\alpha /(1-\alpha)}}-1\right] \psi_{O}^{N, N}>\left[\frac{1}{\left(w^{S}\right)^{\alpha /(1-\alpha)}}-1\right] \psi_{I}^{N, N}
$$

Since $\psi_{k}^{N, N}=\psi_{k}^{N}$, this inequality follows from the reasoning we used to establish (A1). Hence $\Theta_{I S S, O S S}<\Theta_{I N N, O N N}$. To conclude, note that the boundaries between $\{I, S, S\}$ and $\{I, N, N\}$, between $\{I, N, N\}$ and $\{O, S, S\}$, and between $\{O, S, S\}$ and $\{O, N, N\}$, are upward sloping straight lines. None of them is a ray through the origin, because $g^{S}>0$. 


\section{References}

[1] Antràs, Pol. "Firms, Contracts, and Trade Structure." Quarterly Journal of Economics 118, November 2003: 1374-1418.

[2] Antràs, Pol and Elhanan Helpman. "Global Sourcing." Journal of Political Economy 112, July 2004: 552-580.

[3] Grossman, Gene M. and Helpman, Elhanan. "Integration versus Outsourcing in Industry Equilibrium." Quarterly Journal of Economics 117, February 2002: 85-120.

[4] Grossman, Gene M. and Helpman, Elhanan. "Managerial Incentives and the International Organization of Production." Journal of International Economics 63, July 2004: 237-262.

[5] Grossman, Gene M. and Helpman, Elhanan. "Outsourcing in a Global Economy." Review of Economic Studies, 2005 (forthcoming).

[6] Grossman, Gene M., Elhanan Helpman and Adam Szeidl. "Optimal Integration Strategies for the Multinational Firm." CEPR Discussion Paper No. 4477, 2004.

[7] Marin, Dalia and Tierry Verdier. "Power Inside the Firm and the Market: A General Equilibrium Approach." CEPR Discussion Paper No. 3526, 2002 .

[8] Marin, Dalia and Tierry Verdier. "Globalization and the Empowerment of Talent." CEPR Discussion Paper No. 4129, 2003.

[9] Marsh, Peter, "A Little Local Difficulty in the Supply Chain." Financial Times, June $23,2004$.

[10] Melitz, Marc J. "The Impact of Trade on Intra-Industry Reallocations and Aggregate Industry Productivity." Econometrica 71, November 2003: 1695-1725.

[11] Puga, Diego and Daniel Trefler. "Knowledge Creation and Control in Organizations." NBER Working Paper No. 9121, 2002. 


\section{THE FOERDER INSTITUTE FOR ECONOMIC RESEARCH and THE SACKLER INSTITUTE FOR ECONOMIC STUDIES \\ The Eitan Berglas School of Economics Tel-Aviv University}

\section{Recent List of Working Papers}

\begin{tabular}{|c|c|}
\hline $28-2002$ & $\begin{array}{l}\text { Maristella Botticini } \\
\text { Zvi Eckstein }\end{array}$ \\
\hline 29-2002 & Zvi Hercowitz \\
\hline $30-2002$ & $\begin{array}{l}\text { Jeffrey Church } \\
\text { Neil Gandal } \\
\text { David Krause }\end{array}$ \\
\hline $1-2003$ & $\begin{array}{l}\text { Zvi Eckstein } \\
\text { Yoram Weiss }\end{array}$ \\
\hline $2-2003$ & $\begin{array}{l}\text { Bernhard Eckwert } \\
\text { Itzhak Zilcha }\end{array}$ \\
\hline $3-2003$ & $\begin{array}{l}\text { Chaim Fershtman } \\
\text { Oren Bar-Gill }\end{array}$ \\
\hline $4-2003$ & $\begin{array}{l}\text { Hans K. Hvide } \\
\text { Yoram Weiss }\end{array}$ \\
\hline $5-2003$ & $\begin{array}{l}\text { Assaf Razin } \\
\text { Efraim Sadka }\end{array}$ \\
\hline $6-2003$ & $\begin{array}{l}\text { Assaf Razin } \\
\text { Efraim Sadka }\end{array}$ \\
\hline $7-2003$ & $\begin{array}{l}\text { Yossi Hadar } \\
\text { David Pines }\end{array}$ \\
\hline 8-2003 & $\begin{array}{l}\text { Tomer Blumkin } \\
\text { Efraim Sadka }\end{array}$ \\
\hline
\end{tabular}

From Farmers to Merchants: A Human Capital Interpretation of Jewish Economic History

Concentration of Capital Ownership and Investment Fluctuations

Indirect Network Effects and Adoption Externalities

On the Wage Growth of Immigrants: Israel, 1990-2002

The Effect of Better Information on Income Inequality

Law and Preferences

Cultural Diversity, Status Concerns and the Organization of Work

Privatizing Social Security Under Balanced-Budget Constraints: A Political-Economy Approach

A Brazilian-Type Debt Crisis: Simple Analytics

Population Growth and its Distribution between Cities:

Positive and Normative Aspects

Income Taxation with Intergenerational Mobility: Can Higher Inequality Lead to Less Progression

Foerder Institute for Economic Research, Tel-Aviv University, Tel-Aviv, 69978 Israel, Tel: 972-3-640-9255; fax: 972-3-640-5815; e-mail: foerder@post.tau.ac.il Papers from 2000 onwards (and some from 1998 and1999) can be downloaded from our website as follows: http://econ.tau.ac.il/research/search workingPapers.asp 


\begin{tabular}{|c|c|c|}
\hline $9-2003$ & $\begin{array}{l}\text { Michele Piccione } \\
\text { Ariel Rubinstein }\end{array}$ & $\begin{array}{l}\text { Two Tales of Power and Distribution of Wealth } \\
\text { in the Jungle }\end{array}$ \\
\hline $10-2003$ & $\begin{array}{l}\text { Jacob Glazer } \\
\text { Ariel Rubinstein }\end{array}$ & A Model of Optimal Persuasion Rules \\
\hline $11-2003$ & Manuel Trajtenberg & Defense R\&D in the Anti-terrorist Era \\
\hline $12-2003$ & $\begin{array}{l}\text { Yossi Hadar } \\
\text { David Pines }\end{array}$ & $\begin{array}{l}\text { On the Market Failure in a Dixit-Stiglitz Setup with Two } \\
\text { Trading Cities }\end{array}$ \\
\hline $13-2003$ & Dana Heller & Inter-Generational Risk Sharing through Social Convention \\
\hline 14-2003 & Oved Yosha & Financing Innovation: Is Transparency a Two-Edged Sword? \\
\hline $15-2003$ & $\begin{array}{l}\text { Casey B. Mulligan } \\
\text { Yona Rubinstein }\end{array}$ & $\begin{array}{l}\text { Household vs. Personal Accounts of the U.S. Labor Market, } \\
\text { 1967-97 }\end{array}$ \\
\hline $16-2003$ & $\begin{array}{l}\text { Allan Drazen } \\
\text { Nuno Limão }\end{array}$ & $\begin{array}{l}\text { Government Gains from Self-Restraint: A Bargaining Theory } \\
\text { of Inefficient Redistribution Policies }\end{array}$ \\
\hline $17-2003$ & $\begin{array}{l}\text { Aviad Heifetz } \\
\text { Martin Meier } \\
\text { Burkhard C. Schipper }\end{array}$ & Interactive Unawareness and Speculative Trade \\
\hline $18-2003$ & $\begin{array}{l}\text { Michele Piccione } \\
\text { Ariel Rubinstein }\end{array}$ & Equilibrium in the Jungle \\
\hline $19-2003$ & $\begin{array}{l}\text { Michele Piccione } \\
\text { Ariel Rubinstein }\end{array}$ & The Curse of Wealth and Power \\
\hline $20-2003$ & $\begin{array}{l}\text { Bernhard Eckwert } \\
\text { Itzhak Zilcha }\end{array}$ & Improvement in Information, Income Inequality and Growth \\
\hline $21-2003$ & Ran Spiegler & The Market for Quacks \\
\hline $22-2003$ & $\begin{array}{l}\text { Gerard J. van den Berg } \\
\text { Zvi Eckstein }\end{array}$ & Empirical Labor Search: A Survey \\
\hline 23-2003 & $\begin{array}{l}\text { Juan de Dios Tena } \\
\text { Horrillo }\end{array}$ & $\begin{array}{l}\text { The Impact of Non-Financial Factors in Heterogeneous } \\
\text { Sectoral Price and Output }\end{array}$ \\
\hline $1-2004$ & $\begin{array}{l}\text { Tomer Blumkin } \\
\text { Efraim Sadka }\end{array}$ & Minimum Wage with Optimal Income Taxation \\
\hline $2-2004$ & $\begin{array}{l}\text { Gene M. Grossman } \\
\text { Elhanan Helpman }\end{array}$ & Optimal Integration Strategies for the Multinational Firm \\
\hline $3-2004$ & $\begin{array}{l}\text { Pol Antras } \\
\text { Elhanan Helpman }\end{array}$ & Global Sourcing \\
\hline $4-2004$ & $\begin{array}{l}\text { Itzhak Gilboa } \\
\text { Nicolas Vieille }\end{array}$ & Majority Vote Following a Debate \\
\hline $5-2004$ & $\begin{array}{l}\text { Antoine Billot } \\
\text { Itzhak Gilboa } \\
\text { Dov Samet } \\
\text { David Schmeidler }\end{array}$ & Probabilities: Frequencies Viewed in Perspective \\
\hline
\end{tabular}

Foerder Institute for Economic Research, Tel-Aviv University, Tel-Aviv, 69978 Israel, Tel: 972-3-640-9255; fax: 972-3-640-5815; e-mail: foerder@post.tau.ac.il Papers from 2000 onwards (and some from 1998 and1999) can be downloaded from our website as follows: http://econ.tau.ac.il/research/search workingPapers.asp 


\begin{tabular}{|c|c|c|}
\hline $6-2004$ & $\begin{array}{l}\text { Enriqueta Aragones } \\
\text { Itzhak Gilboa } \\
\text { Andrew Postlewaite } \\
\text { David Schmeidler }\end{array}$ & Fact-Free Learning \\
\hline 7-2004 & $\begin{array}{l}\text { Zvi Eckstein } \\
\text { Daniel Tsiddon }\end{array}$ & $\begin{array}{l}\text { Macroeconomic Consequences of Terror: Theory } \\
\text { and the Case of Israel }\end{array}$ \\
\hline 8-2004 & $\begin{array}{l}\text { Gadi Barlevy } \\
\text { Daniel Tsiddon }\end{array}$ & Earnings Inequality and the Business Cycle \\
\hline 9-2004 & Ariel Rubinstein & Instinctive and Cognitive Reasoning: Response Times Study \\
\hline $10-2004$ & $\begin{array}{l}\text { Maristella Botticini } \\
\text { Zvi Eckstein }\end{array}$ & $\begin{array}{l}\text { Jewish Occupational Selection: Education, Restrictions or } \\
\text { Minorities? }\end{array}$ \\
\hline $11-2004$ & $\begin{array}{l}\text { Maristella Botticini } \\
\text { Zvi Eckstein }\end{array}$ & $\begin{array}{l}\text { From Farmers to Merchants: A Human Capital Interpretation of } \\
\text { Jewish Economic History }\end{array}$ \\
\hline $12-2004$ & $\begin{array}{l}\text { Arturo Galindo } \\
\text { Leonardo Leiderman }\end{array}$ & Living with Dollarization and the Route to De-Dollarization \\
\hline $13-2004$ & $\begin{array}{l}\text { Eddie Dekel } \\
\text { Yossi Feinberg }\end{array}$ & A True Expert Knows which Question Should be Asked \\
\hline $14-2004$ & $\begin{array}{l}\text { Itzhak Gilboa } \\
\text { Andrew Postlewaite } \\
\text { David Schmeidler }\end{array}$ & $\begin{array}{l}\text { Rationality of Belief Or: Why Bayesianism is neither necessary nor } \\
\text { sufficient for rationality }\end{array}$ \\
\hline $15-2004$ & $\begin{array}{l}\text { Itzhak Gilboa } \\
\text { Offer Lieberman } \\
\text { David Schmeidler }\end{array}$ & Empirical Similarity \\
\hline $16-2004$ & $\begin{array}{l}\text { Antoine Billlot } \\
\text { Itzhak Gilboa } \\
\text { David Schmeidler }\end{array}$ & Axiomatization of an Exponential Similarity Function \\
\hline $17-2004$ & $\begin{array}{l}\text { Eddie Dekel } \\
\text { Matthew O. Jackson } \\
\text { Asher Wolinsky }\end{array}$ & Vote Buying \\
\hline $18-2004$ & Ariel Rubinstein & A Skeptic's Comment on the Studies of Economics \\
\hline $19-2004$ & $\begin{array}{l}\text { Michele Piccione } \\
\text { Ariel Rubinstein }\end{array}$ & Luxury Prices: An Expository Note \\
\hline $20-2004$ & $\begin{array}{l}\text { Sarit Cohen-Goldner } \\
\text { Zvi Eckstein }\end{array}$ & $\begin{array}{l}\text { Estimating the Return to Training and Occupational } \\
\text { Experience: The Case of Female Immigrants }\end{array}$ \\
\hline $21-2004$ & $\begin{array}{l}\text { Chaim Fershtman } \\
\text { Ariel Pakes }\end{array}$ & $\begin{array}{l}\text { Finite State Dynamic Games with Asymmetric Information: } \\
\text { A Computational Framework }\end{array}$ \\
\hline $22-2004$ & $\begin{array}{l}\text { Kfir Eliaz } \\
\text { Ran Spiegler }\end{array}$ & Contracting with Diversely Naïve Agents \\
\hline 23-2004 & Ran Spiegler & Competition over Agents with Boundedly Rational Expectations \\
\hline
\end{tabular}

Foerder Institute for Economic Research, Tel-Aviv University, Tel-Aviv, 69978 Israel, Tel: 972-3-640-9255; fax: 972-3-640-5815; e-mail: foerder@post.tau.ac.il Papers from 2000 onwards (and some from 1998 and1999) can be downloaded from our website as follows: http://econ.tau.ac.il/research/search workingPapers.asp 
Legal, Actual and Desirable Independence:

A Case Study of the Bank of Israel

Should the Bank of Israel Have a Growth Target? What are the Issues?

1-2005 Elhanan Helpman

Complementarities between Outsourcing and

Gene M. Grossman

Foreign Sourcing

$2-2005$

Adam Szeidl

A Protectionist Bias in Majoritarian Politics 